\title{
Kış Turizmi Potansiyeli Açısından Muş İli’nin SWOT Analizi İle Değerlendirilmesi
}

\section{The Evaluation With SWOT Analysis Of The Muş Province In Terms Of Winter Tourism Potential}

\author{
Emin Arslan ${ }^{\text {a, }}$, Hakan Kendir ${ }^{\text {b }}$ \\ ${ }^{a}$ Dr. Öğr. Üyesi, Tokat Gaziosmanpaşa Üniversitesi, Zile Dinçerler Turizm İşletmeciliği ve Otelcilik Y.O., Gastronomi ve Mutfak Sanatları Bölümü, 60400, \\ Tokat/Türkiye. \\ ORCID: 0000-0003-1592-8162 \\ ${ }^{\text {b }}$ Dr. Öğr. Üyesi, Tokat Gaziosmanpaşa Üniversitesi, Zile Dinçerler Turizm İşletmeciliği ve Otelcilik Y.O., Turizm İşletmeciliği ve Otelcilik Bölümü, 60400, \\ Tokat/Türkiye. \\ ORCID: 0000-0002-1356-1339
}

\section{MAKALE BILGIISI}

\section{Makale Geçmiși:}

Başvuru tarihi: 01 Şubat 2019

Düzeltme tarihi: 02 Mayıs 2019

Kabul tarihi: 10 Mayıs 2019

\section{Anahtar Kelimeler:}

Muş

Turizm

Kış Turizmi

\section{ART ICLE INFO}

\section{Article history:}

Received 01 February 2019

Received in revised form 02 May 2019

Accepted 10 Mays 2019

\section{Keywords:}

Muş

Tourism

Winter Tourism

\section{ÖZ}

Türkiye'nin Doğu Anadolu Bölgesi’nde yer alan illerde, kış turizmine yönelik önemli bir potansiyelin bulunduğu ancak belli merkezlerde yatırımların yoğunlaştığı görülmektedir. Geçmişte var olan terör olaylarının son yıllarda bitirilmesiyle birlikte Doğu Anadolu Bölgesi'nin kış turizmine yönelik daha fazla yatırım çekmesi olasıdır. Ancak Muş ili kış turizmi yatırımı anlamında henüz istenilen noktada bulunmamaktadır. Bu çalışma kapsamında, kış mevsiminin oldukça sert geçtiği ve kış turizmine yönelik (Güzeltepe Kayak Merkezi gibi) imkânların bulunduğu Muş ilinde, kış turizmi potansiyelinin değerlendirilmesi ve kış turizmi olanaklarının ortaya konması amaçlanmaktadır. Çalışma kapsamında GZTF analizi yöntemi kullanılmıştır. Yapılan bu araştırma ile Muş ilinin bir kış turizmi destinasyonu olarak hak ettiği konuma ulaştırılabileceğinin karar vericiler tarafından fark edilmesi hedeflenmektedir.

\begin{abstract}
A B S T R A C T
It is observed that there is a significant potential for winter tourism especially in the provinces of Eastern Anatolia Region in Turkey, but investments are concentrated in certain centers. With the completion of past terrorist events in the past years, it is possible for the Eastern Anatolia Region to attract more investment for winter tourism. However, Muş province is not yet at the desired point in terms of winter tourism investment. In the scope of this study, it is aimed to evaluate the potential of winter tourism and to reveal the possibilities of winter tourism in the province of Mus where winter season is quite harsh and there are facilities for winter tourism (such as Güzeltepe Ski Center). SWOT method was used in this scope of study. With this research, it is aimed that to be realized by the decision makers that the province of Muş can be reached as a winter tourism destination.
\end{abstract}

\section{Giriş}

Dünyada turizm hareketliliği hızla artmaktadır. Birleşmiş Milletler Dünya Turizm Örgütü'nün verilerine göre, 2017 y1lında 1.3 milyardan fazla insanın turizm faaliyetlerine katıldı ̆̆ 1 belirtilmektedir. 2030 yılında ise bu sayının 1.8 milyar kişiye çıkacağı tahmin edilmektedir (UNWTO, 2018). Dünya turizm gelirleri 2016 y1lında 1.22 trilyon \$ olarak hesaplanmıştır. Ayrıca gelecek yıllarda da dünya turizm hareketlerine katılan kişi sayısına paralel olarak turizm gelirlerinin de artacağı tahmin edilmektedir (UNWTO, 2017).
Özellikle ekonomik olarak gelişmekte olan ülkeler için hayati önem taşıyan turizm faaliyetleri söz konusu ülke ekonomileri açısından önemli bir gelir kaynağı oluşturmaktadır. Türkiye de gelişmekte olan ülkeler kategorisinde yer aldığından dolayı, turizm faaliyetleri Türkiye'nin genel ekonomisi içerisinde oldukça önemli bir paya sahiptir. 2017 yılında Türkiye'de GSYH (Gayrisafi Yurtiçi Hasıla) rakamları 851 milyar \$ seviyesinde bulunmaktadır (TÜIK, 2018a). Turizm gelirleri ise 2017 yılında 26 milyar \$ olarak gerçekleşmiştir (TÜİK,

\footnotetext{
* Sorumlu yazar/Corresponding author

e-posta: emin.arslan@gop.edu.tr
} 
2018b). Turizmin Türkiye ekonomisi içerisindeki payı \%3’ün biraz üzerinde bulunmaktadır. Bu oran ABD ve Almanya gibi gelişmiş ülkelerde \%1'ler düzeyindedir. Dolayısıyla turizm Türkiye ekonomisi açısından gelişmiş ülkelere göre daha büyük önem arz etmektedir.

Türkiye'yi 2017 yılında yaklaşık 38,5 milyon turist ziyaret etmiştir (TÜİK, 2018b). 2018 yılının ilk on ayında da (OcakEkim) Türkiye'yi ziyaret eden turist sayısı 41 milyonu aşmıştır (NTV, 2018a). Gelen turistlerin Türkiye'de belirli bölgelerde (Akdeniz ve Ege sahilleri ile İstanbul) yoğunlaştığ bilinmektedir. Ancak bu bölgelerde taşıma kapasitesinin aşılmak üzere olduğu veya aşıldığı göze çarpmaktadır. Bunun sonucu olarak çevresel, tarihsel ve kültürel tahribatlar yaşanmakta ve turizmde sürdürülebilirlik olumsuz etkilenmektedir. Gelecekte bu durumun vereceği zararları azaltmak adına, 2023 Türkiye Turizm Stratejisi'nde turizm hareketlerinin diğer bölgelere de yayılması bir devlet politikası olarak planlanmaktadır. $\mathrm{Bu}$ noktadan hareketle çalışma kapsamında Türkiye'nin Doğu Anadolu Bölgesi'nde bulunan ve özellikle kış mevsiminin oldukça sert geçtiği Muş İli’nin kıș turizm potansiyelini ortaya koymak ve geleceğe dair öngörülerde bulunmak amaçlanmaktadır. $\mathrm{Bu}$ amaç doğrultusunda Muş ilinde kış turizmi ile ilgili ikincil veri kaynaklarından yararlanılarak alanyazın taraması yapılmıştır. Muş ilinin öne çıkan kış turizmi olanakları detaylı olarak sunulmuş ve alanyazın taramasından elde edilen veriler GZTF (SWOT) analizi yöntemiyle değerlendirilmiştir.

\subsection{Muş İli ve Turizm Potansiyeli}

\subsection{Muş İli Hakkında Genel Bilgiler}

Muş ili Türkiye'nin doğusunda yer almaktadır ve 2017 yılı itibariyle nüfusu 404.544'tür (TÜİK, 2018c). Muş ilinde kara iklimi hüküm sürmekte, kışlar sert ve uzun geçmektedir. Toprak yaklaşık 105 gün karla kaplıdır (Şengün ve Kıranşan, 2016). Yılın yaklaşık 100 güne yakını $0^{\circ} \mathrm{C}$ altında geçer. Yaz mevsiminde ise yaklaşık 60 gün $+30^{\circ} \mathrm{C}$ 'nin üzerindedir. Yıllık yağış miktarı il merkezinde 761 mm'dir. Yağıșların önemli bir kısmı kış aylarında ve kar şeklinde görülmektedir. Yazlar az yağışlı ve sıcak geçer. İl merkezinde sıcaklık yıl boyunca $34,4^{\circ} \mathrm{C}$ ile $+41,6^{\circ} \mathrm{C}$ arasinda seyretmektedir (MGM, 2018).

Doğu Anadolu'nun yüksek düzlüklerinde yer alan Muş'un ilkçağ tarihi Urartular dönemiyle başlar. Muş’un önemi Urartu Krallı̆̆ının batı yolunda merkezi bir konumda bulunmasından kaynaklanıyordu. Başkent Tuşpa'dan (Van) batıya giden yol Malazgirt Ovasını geçtikten sonra Murat Irmağı vadisi boyunca Varto'nun güneyinden Muş Ovasına, buradan da batıya, daha sonra Bingöl üstünden Elazığ-Malatya yolu ile de Orta Anadolu ve Kuzey Suriye'ye uzanıyordu. Muş, Urartu döneminden sonra sirasıyla; Medler, Persler, Romalılar, Partlar, Ermeniler, Sasaniler, Bizanslılar ve Arapların hâkimiyetine girmiştir. Daha sonraki dönemlerde Muş, Bizans ve Arapların uzun yıllar süren mücadelelerinin ardından 1071 yılında Malazgirt Savaşı'nda Selçuklu ordularının Bizans ordularını yenmesiyle Türklerin hâkimiyetine girmiştir. Moğollar ve Anadolu Selçuklu Devleti arasında geçen 1243 Kösedağ Savaşı'ndan sonra Moğollar bölgeye hâkim olmuştur. 1514 Çaldıran Savaşı'na kadar sırasıyla, İlhanlılar, Karakoyunlular, Akkoyunlular, Timur, Safeviler bölgeye hâkim olmuştur. Çaldıran Savaşı’nda Osmanlı Devletinin Safevileri yenmesiyle birlikte Doğu Anadolu Osmanlı hâkimiyetine girmiştir. I. Dünya Savaşı'ndan sonra çok kısa süre Ruslar bölgeye hâkim olsalar da Muş halkının ve Türk Ordusunun gayretleriyle 1917 yılında bölge tamamen Ruslardan temizlenmiştir (Muş Valiliği, 2018a). Bu kadar çok uygarlığın Muş’ta hâkim olması çok sayıda tarihi ve kültürel değerlerin oluşmasına neden olmuștur. Dolayısıyla turizm açısından bu değerler günümüzde Muş destinasyonu için çok önemli birer çekicilik potansiyeli barındırmaktadır.

\subsection{Muş İlinde Turizm}

Türkiye'de illerin kalkınmışlık seviyesini ortaya koyan ve en önemli göstergelerden biri olan, TÜİK (Türkiye İstatistik Kurumu)'in 2015 yılında yayımladığı "İllere Göre Yaşam İndeksi” verileri, Muş ilinin tüm iller içerisinde 81. sırada olduğunu göstermektedir (TÜİK, 2018d). Özellikle sanayinin gelişmediği bölgelerde turizm, bölgeler arası kalkınmışlık seviyesini dengelemekte ve göçü engellemektedir. Dolayısıyla turizm faaliyetleri az gelişmiş veya gelişmekte olan bölge ekonomileri için büyük önem arz etmektedir. Muş, Türkiye'nin doğusunda az gelişmiş bir bölgede yer aldığından dolayı turizm faaliyetlerinin burada yoğunlaşması bölgenin gelişimi ve batıdaki gelişmiş illere olan göçün engellenmesi açısından oldukça önemlidir.

\section{Ulaşım:}

Muş ili Doğu Anadolu Bölgesi'nde özellikle ulusal ve uluslararası transit geçiş güzergâhlarında yer almaktadır. Karayolu, demiryolu ve havayolu ile ilin ulaşım olanakları desteklenmektedir. İran-Van üzerinden Batı Anadolu'ya gitmekte olan taşımacılık ve lojistik amaçlı kullanılan ulaşım yolları Muş üzerinden geçmektedir. Öte yandan İranNahçıvan-Ağrı güzergâhı üzerinden Güneydoğu Anadolu ve Akdeniz yönüne devam eden transit yol yine Muş üzerinden geçmektedir (Muş Valiliği, 2018b). Dolayısıyla Muş, Doğu Anadolu'da önemli bir kavşak noktası konumunda bulunmaktadır. $\mathrm{Bu}$ nedenle her ne kadar illere göre yaşam indeksinde son sırada bulunsa da gelecekte gelişim göstermek açısından önemli bir potansiyele sahiptir.

1955 yılında yapımı tamamlanan Haydarpaşa-Tatvan, VanKapıköy, Tatvan-Haydarpaşa yolcu ve yük taşımacılığı yapılan demiryolu hattı, Muş'un gelişiminde önemli bir rol oynamıştır. 1972 yılında demiryolunun İran'nın başkenti Tahran'a kadar uzatılmasıyla uluslararası demiryolu güzergâhında Muş ili önemli bir konuma sahip olmuştur. 2014 yılında Muş Valiliği'nin yayımladığı verilere göre demiryolu vasitasıyla seyahat eden yolcu sayısı 3.341 kişidir (Muş Valiliği, 2018b). Bu veriler göstermektedir ki, Muş demiryolu yolcu taşımacılığı anlamında var olan potansiyelini tam olarak kullanamamaktadır. Örneğin, Doğu Ekspresi gibi Van Gölü Ekspresi'nin de son yıllarda demiryolu taşımacılığında trend olduğu ve Doğu Anadolu'ya uzanan güzergahlarda Muş için önemli firsatlar barındırdığı göze çarpmaktadır (NTV, 2018b).

1992 yılında sivil trafiğe açılan Muş Sultan Alparslan Havalimanı'nın yolcu kapasitesi, Ulaştırma Bakanlığı tarafından 2017 yılında tamamlanan genişletme çalışması neticesinde 2 milyon yolcu kapasitesine çıkarılmıştır (Yeni Şafak, 2017). Dolayısıyla yolcu kapasitesindeki bu artış neticesinde, daha fazla yerli ve yabancı turistin Muş iline ulaşımı kolaylaşmıştır. Şekil 1'de Muş Sultan Alparslan Havalimanı'nın 2007-2018 yılları arası toplam yolcu trafiği görülmektedir. 
Şekil 1. Yıllar İtibariyle Muş Sultan Alparslan Havalimanı İçDiş Hatlar Yolcu Trafiği

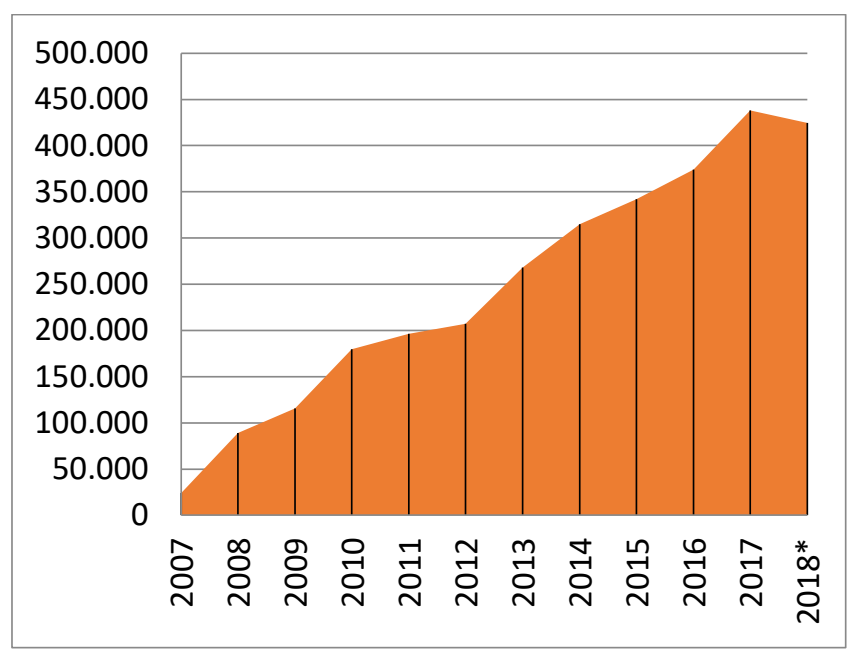

\section{Kaynak: (DHMİ, 2018) *2018 Ocak-Kasım Dönemi}

Muş Sultan Alparslan Havalimanı'nın iç-dış hatlar toplam yolcu trafiği 2007 y1lında yaklaşık 24.000 yolcu iken 2017 yılına gelindiğinde yolcu sayısının 438.037'ye ulaştığı görülmektedir. 2018 yılının ilk on bir (Ocak-Kasım) ayında ise 424.677 yolcuya ulaşmıştır (DHMİ, 2018). Bu verilerden hareketle, 2018 yılı tamamlandığında yolcu sayısının 440.000'nin üzerine çıkması muhtemeldir.

\section{Muş Ilinin Turistik Çekicilikleri:}

Turizm olayı, coğrafi bir mekânda gerçekleşmekle beraber, gerçekleştiği mekânın unsurları ile çeşitli iletişim ve etkileşim faaliyetlerini de kapsamaktadır. Dolayısıyla turist hareketlerinin bir destinasyona yönelmesinde, destinasyonun çekiciliklerinin yanında, turist motivasyonlarının da anlaşılması önemlidir. Motivasyona neden olan faktörler, turistlerin ihtiyaç duydukları maddi ve manevi durumlar olarak değerlendirilebilir. Bu bakımdan artık günümüzde turistlerin istekleri doğrultusunda maddi ve manevi çekicilikler tespit edilerek, turistler turistik çekim merkezlerine yönlendirilmeye çalışılmaktadır (Çetin, 2017: 47).

Muş, Türkiye'de turizm faaliyetlerinin az olduğu illerden biridir. Muş ilinde kış turizmi, dağ sporları, eko turizm ve av turizmi için uygun alanlar bulunmaktadır. Bununla beraber, kültür ve inanç turizmi açısından da değerlendirilebilecek olanaklar mevcuttur. Tarihi ve kültürel değerler bakımından il merkezinde; Alaaddin Camii, Ulu Cami, Hacı Şeref Camii, Kesikbaş Türbesi, Arak Manastırı, Çengilli Kilisesi, Meryem Ana Kilisesi, Çanlı Kilise, Tarihi Murat Köprüsü ile Muş Kalesi, Hasbet Kalesi, Aslanlı Han ve Yıldızlı Han yer almaktadır. Malazgirt ilçesinde ise Malazgirt Kalesi, Katerin Kalesi, T1kızlı Kalesi, Dolabaş Höyüğü, Bostankale Höyüğü ve Aradere Köyü Mezarlığı; Varto ilçesinde de Kayalıdere Ören Yeri bulunmaktadır. Ayrıca, il genelinde Hamurpet, Kazan ve Kaz Gölleri turizm açısından değerlendirilebilecek doğal göllerdir (Aslan, 2013; Muş Valiliği İl Kültür ve Turizm Müdürlüğü, 2018).

Muş ilinin adeta simgesi haline gelmiş olan Muş Lalesi, her y1l bahar aylarında bütün ovayı kaplamaktadır. Muş Lalesi'ni diğer lalelerden ayıran en önemli özelliği kırmızı renge ve "mızraksı" bir yapıya sahip olmasıdır. Her yıl nisan ayının sonlarında Muş'un Korkut ilçesinde düzenlenen ve geleneksel hale gelmiş olan "Lale Festivali" yörede bir çekicilik unsuru olarak ön plana çıkmaktadır (Gezimanya, 2018; Milliyet, 2018). Selçuklu Sultanı Alparslan'ın Bizans İmparatoru Romen Diyojen'i 1071 yılında mağlup ettiği Malazgirt Ovası'nda her yıl 25-26 Ağustos'ta düzenlenen Malazgirt Zaferi'nin yıldönümü kutlamaları nedeniyle, Türkiye'nin hemen hemen her bölgesinden insanlar yöreye gelmektedir. Dolayısıyla Malazgirt Zaferi etkinlikleri yörede önemli bir turizm hareketliliği yaratmaktadır (Anadolu Ajansı, 2018).

\subsection{Muş İlinde Kış Turizmi Olanakları}

Türkiye'de önemli alternatif turizm çeşitleri arasında yer alan kış turizmi son yıllarda hızlı bir gelişîm göstermektedir. Bu gelişimle beraber yerli ve yabancı ziyaretçilere hizmet sağlayabilecek önemli potansiyele ulaşmıştır. Kış turizmi kapsamında Erzurum ilinde düzenlenen 57 ülkeden yaklaşı 3500 sporcunun katıldığı 2011 Dünya Üniversiteler Kış Oyunları (Universiade) ve 40 ülkeden 807 sporcunun katıldığı 2017 Avrupa Gençlik Olimpik Kış Festivali (EYOF-European Youth Olympic Festival) gibi uluslararası organizasyonlar, Türkiye'nin kış sporları anlamında önemli yatırımlar gerçekleştirdiğini ve bu alanda daha fazla sayıda turist çekebilmeyi hedeflediğini ortaya koymaktadır (Silik ve Ünlüönen, 2017: 25). Erzurum gibi Doğu Anadolu Bölgesi’nin diğer illeri de kış turizmi ve kış sporları açısından elverişli ortamlar barındırmaktadır. Muş ili de soğuk iklimi, yüksek dağları, yoğun miktardaki kar yağışı ve uzun kış mevsimiyle kış sporlarına ilgi gösteren turistleri çekebilecek önemli bir potansiyele sahiptir.

Muş kent merkezine ait meteorolojik verilere göre Muş ilinin kış aylarında oldukça soğuk ve kar yağışlı bir iklime sahip olduğu söylenilebilir. İl geneli 1500 - 1700 metre rakımlı oldukça yüksek platolarda yayılmaktadır. Muş kent merkezi deniz seviyesinden 1316 metre yükseklikte yer almaktadır. Yüksek irtifadan dolayı kış aylarında kent merkezi yoğun kar yağışı almakta ve kar kalınlığı önemli seviyelere ulaşmaktadır. Bugüne kadar Muş kent merkezinde ölçülmüş en yüksek kar kalınlığ $163 \mathrm{~cm}$ seviyesindedir (MGM, 2018). Bu seviye, kent merkezinden uzaklaşıp dağlara çıkıldıkça daha da yükselmektedir. Ayrıca Muş, Türkiye'de en yüksek kar kalınlığına sahip iller arasında yer almaktadır (Günal, 2013: 7). Bu anlamda 2850 metre yüksekliğindeki Kurtik Dağı örnek verilebilir. Kurtik Dağı'nda kış aylarında zaman zaman 9-10 metreye ulaşan kar kalınlığı, Nisan ayında bile 1.5-2 metre dolayında olabilmekte ve burada hiçbir tesis olmamasına rağmen uzun kış sezonundan dolayı amatör kayakseverleri bölgeye çekebilmektedir (TRT HABER, 2018). Dolayısıyla Muş ili kış turizmi açısından oldukça uygun bir iklime sahiptir. Son yıllarda Muş ilinde kış turizmine yönelik yatırımlar yapılmaya başlanmıştır. Bu yatırımlardan en çok öne çıkan Güzeltepe Kayak Merkezi'dir.

\section{Güzeltepe Kayak Merkezi:}

Muş Valiliği tarafından 2003 yılında kayak evi inşa edilmesiyle birlikte faaliyete geçen Güzeltepe Kayak Merkezi (Fotoğraf 1), kent merkezine $8 \mathrm{~km}$. mesafede bulunmaktadır (Hürriyet, 2009). 2300 m. rakıma sahip olan kayak merkezinde 
$1300 \mathrm{~m}$. uzunluğunda iki adet pist yer almaktadır. 67 adet olan ask1 sayıs1 2017 yılında yapılan yatırımlar neticesinde 76 adede çıkarılmıştır (Milliyet, 2017a). Ayrıca kayak merkezinde baby-lift, bir adet snowtrack (kar ezme aracı) ve bir adet kar motoru mevcuttur (Muş Vakfi, 2014). Konumu ve kar kalitesi bakımından kış sporlarına katılanlar için cazibe merkezi haline gelebilecek olan Güzeltepe Kayak Merkezi'nde saatte 1000 kişi kapasiteli bir adet teleski faaliyetine devam etmektedir (Muş Valiliği, 2018c).

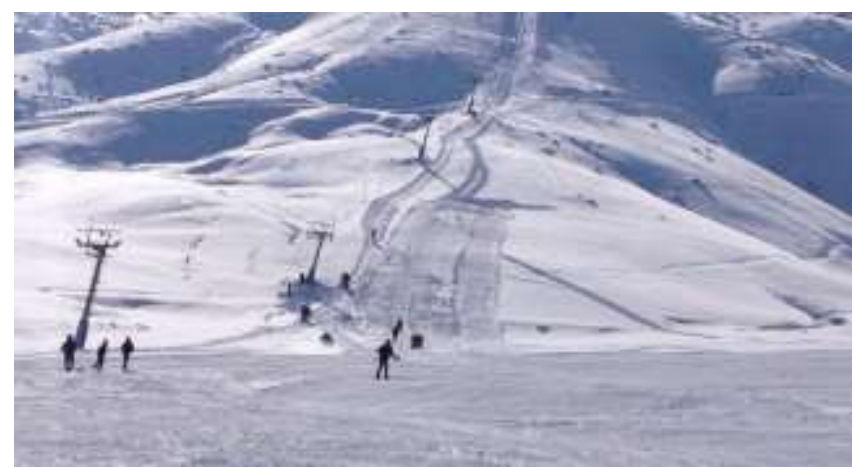

Fotoğraf 1: Güzeltepe Kayak Merkezi (Muş Web, 2015).

\section{Hamurpet (Akdoğan) Gölü:}

Hamurpet diğer adıyla Akdoğan Gölü (Fotoğraf 2) Muş ili sınırları içerisinde yer almaktadır. Akdoğan Göl'ü 2.200 m. rakımında birbirine kıyısı ve kısmi bağlantısı olan 2 gölden oluşmaktadır. Tatlı su yapısına sahip olan Akdoğan Gölü'ne Muş il merkezinden 70 km'lik bir yol vasıtasıyla ulaşılabilmektedir. Varto ilçesinin doğusunda bulunan Büyük ve Küçük Akdoğan Gölleri Muş, Varto ve Hınıs yerleşim merkezlerine sirası ile $71 \mathrm{~km}, 30 \mathrm{~km}$ ve $34 \mathrm{~km}$ uzaklıkta bulunmaktadır. Büyük Akdoğan $2.153 \mathrm{~m}$. rakımda bulunmaktayken, Küçük Akdoğan 2.216 m. rakımda yer almaktadır. Ayrıca Büyük Akdoğan Gölü 11.145 km2 alana ve 21 m. derinliğe sahipken; Küçük Akdoğan Gölü ise 1.545 km2 alana ve $47 \mathrm{~m}$. derinliğe sahiptir. Kış mevsimlerinde donan göllerde (Fotoğraf 3) yaklaşık $40 \mathrm{~cm}$ kalınlığında buz tabakası oluşmaktadır (Tarım ve Orman Bakanlığı, 2018a). Dolayısıyla kış aylarında donan Akdoğan Gölleri turistik amaçlı buz altı dalış faaliyetlerine olanak sağlamaktadır. Buz altı dalışı; buz altında rekreasyon, bilimsel araştırma, kamu güvenliği gibi amaçlarla gerçekleşen, genelde sadece tek bir giriş çıkış noktası olan ayrıca özel prosedür ve ekipman gerektiren dalış türüdür. Buz altı dalışı turistik amaçlarla da yapılmasının yanı sıra normal dalışa ek olarak güvenlik tedbirleri de gerektiren bir dalış türüdür (Asan, 2018: 72).

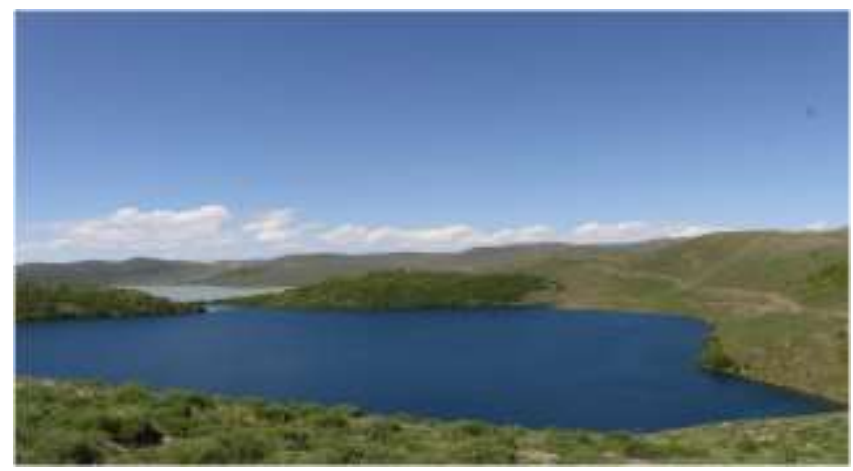

Fotoğraf 2: Akdoğan Gölü (Tarım ve Orman Bakanlığı, 2018a)

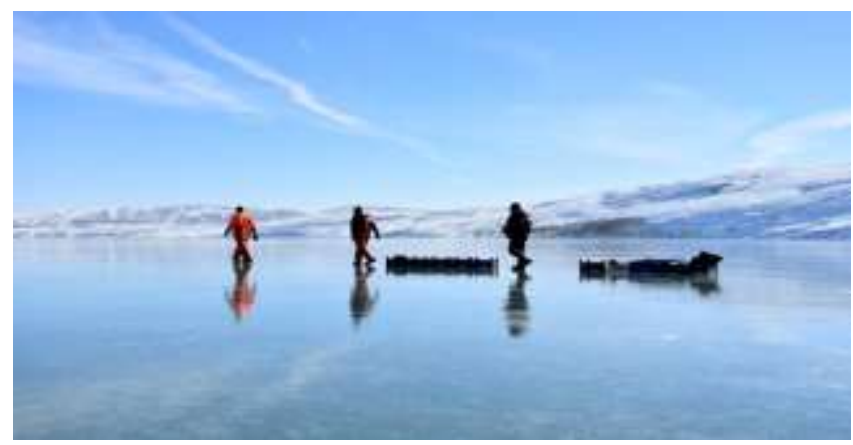

Fotoğraf 3: Donmuş Akdoğan Gölü (Milliyet, 2017)

\section{Kazan (Haçlı) Gölü:}

Kazan Gölü (Fotoğraf 4) volkanik set gölü olarak bilinmektedir. Muş ili Bulanık ilçesinin güneyinde bulunan Haçlı Gölü, Muş, Bulanık ve Malazgirt yerleşim merkezlerine sirasi ile $115 \mathrm{~km}, 7 \mathrm{~km}$ ve $35 \mathrm{~km}$ uzaklıkta bulunmaktadır. Deniz seviyesinden $1.583 \mathrm{~m}$. yükseklikte yer almakta ve 87.7 km2 alanda yayılmaktadır. Kazan Gölü'nde derinlik 7 m.'yi geçmemektedir. Karasal iklimin hüküm sürdüğü Kazan Gölü ve yakın bölgesinde yıllık ortalama yağış miktarı $580 \mathrm{~mm}$., yıllık ortalama sıcaklık değeri ise $7{ }^{\circ} \mathrm{C}$ civarındadır. Kışın donan göl sathında yürüyüş yapılabilmektedir. Bu açıdan göl, kızak ve buz altı dalış gibi kış turizmi faaliyetlerine olanak sağlamaktadır. Kazan Gölü'nün kıyı kısmı taşlık ve çok iri olmayan kayalıklardan oluşmaktadır. Kıyı kuşları genellikle kıyıdaki bu yapı üzerinde dinlenmektedirler. Alanda bulunan kuşlar üreme alanları olarak daha çok Bulanık Ovası'nı kullanmaktadırlar (Tarım ve Orman Bakanlığı, 2018b; Türkiye Kültür Portalı, 2018).

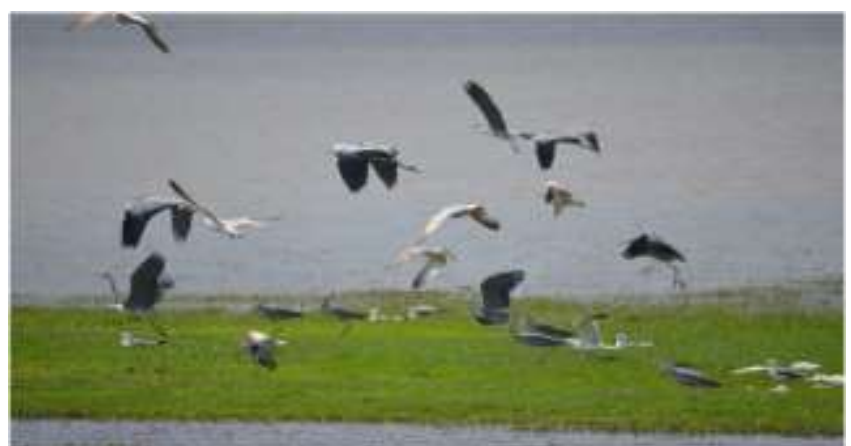

Fotoğraf 4: Kazan (Haçlı) Gölü (Tarım ve Orman Bakanlığı, 2018b). 
Kuşlar gerek bilimsel amaçlarla ve av için gerekse hobiye dayalı sportif aktivite için geçmişten günümüze kadar düzenli olarak izlenmişlerdir. Bununla beraber kuş gözlem turizmi ise her geçen gün daha fazla önem kazanan bir niş pazar özelliği taşımaktadır. Kuş gözlem turizmi dünyada hızlı bir gelişme gösteren ornito turizm kapsamında değerlendirilmekte ve doğa temelli seyahat edenler arasında en fazla gelire sahip olan turist gruplarını kapsamaktadır (Asan vd., 2018: 634). Dolayısıyla Kazan Gölü, kış turizmi faaliyetlerinin yanı sıra kuş gözlem turizmi kapsamında da Muş iline alternatif bir turizm türü olarak katkı sağlama potansiyeline sahiptir.

\subsection{Muş İli Kış Turizminin GZTF (SWOT) Analizi İle Değerlendirilmesi}

GZTF analizi bir stratejinin formüle edilmesine yardımcı olmak için yapılandırılmış bir yöntem olarak bilinmektedir. Ayrica GZTF analizi durum analizi olarak da adlandırılmaktadır. GZTF analizinin amacı, bir duruma yönelik “Güçlü ve Zayıf” yönleri ve aynı durumun çevresinde gelişen "Fırsat ve Tehdit" unsurlarını tanımlamaktır. Söz konusu faktörlerin tanımlanması neticesinde ilgili durumun güçlü yönlerini öne çıkaran, zayıf yönlerini en aza indiren, çevredeki firsatlardan faydalanan ve tehditlere karşı koyan stratejilerin geliştirilmesi mümkündür (Dyson, 2004: 632). Aşağıda bulunan Tablo 1'de Muş ilinin kış turizmine yönelik GZTF matrisi yer almaktadır.

Tablo 1: Muş İli Kış Turizmine İlişkin GZTF Matrisi

\section{GÜÇLÜ YÖNLER}

- Kayak sezonunun uzun
sürmesi.

- Kar kalınlığının fazla olması. - 2 milyon yolcu kapasiteli havalimanının varlığı.

- Güzeltepe Kayak Merkezi'nin faaliyette olması.

- Muş'un transit yollar üzerinde önemli bir kavşak noktada yer almas1.

- Muş'ta farklı alternatif kış turizmi olanaklarının (buz altı dalış gibi) bulunması.

\section{FIRSATLAR}

- Kar kalınlığının çok fazla olduğu ve kış mevsiminin çok uzun sürdüğü Kurtik Dağı'nda, bir kayak merkezinin inşa edilmesine elverişli bir ortamın varlığ́1.

- Van Gölü Ekspresi'nin daha aktif hale getirilmesiyle, Muş'un kış turizmine daha fazla katılımcı sağlanması.

- Gün geçtikçe popüler hale gelen sosyal medya (Facebook, İnstagram, Twitter vb.) platformlarında, Van Gölü Ekspresi vasıtasıyla Muş'un tanıtım olanağının bulunması.
Tablo 1'de yer alan GZTF analizi matrisinde, Muş ili k1Ş turizmine yönelik güçlü ve zayıf yönler ile pazarda yer alan firsat ve tehditler yörenin yapısı dikkate alınarak değerlendirilmiştir. Bu değerlendirmeler yapılırken Muş ili hakkında yayınlanmış olan makaleler, tezler, haberler ve tanıtım materyalleri gibi ikincil veriler incelenerek bir derleme yapılmıştır. Yapılan derleme sonucunda öne çıkan GZTF durumları matrise eklenmiştir.

\section{Sonuç ve Öneriler}

Doğu Anadolu'da yüksek platolar üzerinde yayıllan Muş ili, oldukça soğuk geçen kış mevsimi sayesinde kış turizmine yönelik önemli bir potansiyel barındırmaktadır. Muş'ta özellikle "Güzeltepe Kayak Merkezi" gibi bir yatırımın yapılmış olması başlangıç açısından önemli bir adımdır. Kış turizminde destinasyon çekiciliği yaratmak açısından daha fazla kapasiteli yeni yatırımların yapılması yerinde ve ciddi bir atılım olacaktır. Kayak ve diğer kış sporları, dünya genelinde 70 'den fazla ülkede, mevsime göre sayıları 4-6 bin arasında değişiklik gösteren kayak merkezinde ve yaklaşık 2 bin dolayında otelde her yıl deneyimlenmektedir. Kış turizmi açısından oldukça büyük bir öneme sahip olan kış sporları, yeryüzü üzerinde birçok dağlık bölgenin, büyüme ve ekonomik faaliyetlerine en güçlü katkıyı sağlayan yapıda bulunmaktadır (Tsiotsou, 2006; Tuppen, 2000) ve literatürde önemli bir yere sahiptir (Bonnefoy-Claudet ve Ghantous, 2013: 624; Hungenberg vd., 2013: 313; Kopar ve Çakır, 2015: 65; Birinci vd. 2017: 695; Gürer, 2017: 2; Howstuffworks, 2018).

Muş ili gerek yüksek irtifalarda bulunması bakımından gerekse kış mevsiminin soğuk geçmesi bakımından önemli derecede kış turizm potansiyeli barındıran bir özellik sergilemektedir. Güzeltepe Kayak Merkezi kış turizmi kapsamında kayak sporuna yönelik imkânların yer aldığı bir tesis olarak kapasite yetersizliğine rağmen bölge açısından büyük bir ihtiyaca cevap vermektedir. Öte yandan Muş’ta kış turizmi faaliyetlerinin sadece kayak sporu ile sınırlı kalmaması ve donmuş göllerde buz altı dalış, kış yürüyüşü, buz tırmanışı gibi diğer kış turizmi aktivitelerine de önem verilmesi gerekmektedir. Söz konusu kış turizm faaliyetleri Türkiye'de Erzurum, Sivas, Kars, Ardahan gibi illerde yoğunlaşmaktadır (Arslan vd., 2018). Ancak Muş'un da bu anlamda önemli bir potansiyel barındırdığı bilinmektedir. Bununla beraber Muş ilinin bu potansiyeli harekete geçirmesi kalkınmış̧ık düzeyi açısından diğer bölgelerle olan farkını kapatmak açısından önem arz etmektedir. Özellikle soğuk iklimiyle öne çıkan Muş'ta, kış turizmi faaliyetlerinin yanı sıra Kazan Gölü’nde kuş gözlemciliği gibi alternatif turizm faaliyetlerinin yapılabilme olanağı bulunmaktadır. Turizmin çeşitlendirilmesi açısından bu tür faaliyetler önem taşımakta ve öncü rol oynamaktadır. Bu noktadan hareketle, çalışma kapsamında araştırmacılar tarafından geliştirilen öneriler ise şunlardır:

$\checkmark$ Muş ilinde özellikle Güzeltepe Kayak Merkezi için ihtiyaca cevap verebilecek ve doğal yapıya uygun konaklama tesisi yatırımlarının yapılması hususunda gerekli teşvikler sağlanmalıdır.

$\checkmark$ Son yıllarda trend haline gelen Doğu Ekspresi gibi kış aylarında Doğu Anadolu Bölgesi'ne yapılan tren yolcukları, Van Gölü Ekspresi'nin canlandırılması vasıtasıyla kış aylarında Muş ili için de önemli turizm 
hareketi olușturma potansiyeli barındırmaktadır. Bu sebeple Van Gölü Ekspresi'nin özellikle sosyal medya mecralarında tanıtımının yapılması gerekmektedir.

$\checkmark$ Donmuş göllerde kızaklarla gezinti, fotoğrafçılık, buz altı dalış gibi aktivitelerin öne çıkarılması ve tanıtımının etkin bir şekilde yapılması Muş'un sahip olduğu kaynakların değerlendirilmesi açısından önem arz etmektedir. $\mathrm{Bu}$ konuda yetkili mercilere büyük görevler düşmektedir.

$\checkmark$ Güzeltepe Kayak Merkezi’nde yurtdışında bazı ülkelerdeki kayak merkezlerinde bulunan ancak henüz Türkiye'de çok yaygınlaşmamış olan, en az 10 metre yüksekliğinde yapay bir şelale veya buz duvarı oluşturularak kış turizminde alternatif bir kaynak yaratılabilir.

$\checkmark$ Muş kent merkezinin güneybatısında yer alan $2.850 \mathrm{~m}$. rakımlı, kar kalınlığının Güzeltepe Kayak Merkezi'ne göre daha fazla olduğu ve yağan karın Haziran ayına kadar erimediği Kurtik Dağı'nda, hem kayak severlere hem de dağcılık sporuyla uğraşanlara yönelik tesislerin yapılması Muş iline kış turizmi açısından önemli ölçüde fayda sağlayacaktır.

Sonuç olarak, Muş ilinde kış turizmi başta olmak üzere diğer turizm faaliyetlerinin de çeşitlendirilmesine yönelik yapılan bu çalışma, daha sonraki yıllarda Muş ilinin turizm olanakları ile ilgili yapılacak olan diğer akademik çalışmalara öncülük edebilecek niteliktedir. Muş'un turizm olanaklarına değinen ve bu alanda yapılacak olan uygulamalı ya da teorik farklı akademik araştırmalar, Muş ilinde turizm faaliyetlerinin gelişimi ve Muş ilinin kalkınması açısından faydalı olacaktır.

\section{Kaynakça}

Anadolu Ajans1 (2018). Malazgirt Zaferi Etkinliklerine Vatandaşlardan Yoğun Ilgi. (Erişim: 10.12.2018), https://www.aa.com.tr/tr/gunun-basliklari/malazgirtzaferi-etkinliklerine-vatandaslardan-yogun-ilgi/1238545.

Arslan, E., Kendir, H. \& Asan, H. (2018). Sivas'ın Kış Turizmi Olanakları Kapsamında Rekreasyonel Bir Faaliyet: Donmuş Şelale Tırmanışı. Journal of Recreation and Tourism Research, 5(4), 1-10.

Asan, H. (2018). Kış Turizmi Kapsamında Buz Altı Dalış Turizminin Geliştirilmesi: Sivas Illi Örneği. Uluslararası Sivas Turizmi Kongresi Yıldızdağı, Kış Turizmi Temalı. 23-25 Şubat 2018, Sivas.

Asan, H., Yalçın, H. M. \& Şimşek, E. (2018). Sivas İli Kuş Gözlem Turizmi Potansiyelinin Değerlendirilmesi. Akademik Sosyal Araştırmalar Dergisi, 6(74), 630-655.

Birinci, S., Kaymaz, K.Ç. \& Dumlu, Y. (2017). Macera Turizmi Açısından Değerlendirilmesi Gereken Bir Kış Doğa Sporu: Buz Tırmanışl. 6th International Conference of Strategic Research in Social Science and Education. 1214 May 2017, Prague/Czech Republic. pp. 684 - 705.

Bonnefoy-Claudet, L. \& Ghantous, N. (2013). Emotions' impact on tourists' satisfaction with ski resorts: the mediating role of perceived value. Journal of Travel \& Tourism Marketing, 30, 624-637.

Çetin, İ. (2017). Yeni Gelişen Turistik Destinasyonlar ve Van'1 Ziyaret Eden İranlı Turistlerin Özellikleri. Ahi Evran Üniversitesi Sosyal Bilimler Enstitüsü Dergisi, 3(1), 44-59.
DHMİ (2018). Muş Sultan Alparslan Havalimanı Yolcu Trafiği Istatistikleri. (Erişim: 07.12.2018), https://www.dhmi.gov.tr/sayfalar/istatistik.aspx.

Dyson, R. G. (2004). Strategic Development and SWOT Analysis At The University of Warwick. European Journal of Operational Research, (152), 631-640.

Gezimanya (2018). Muş. (Erişim: 10.12.2018), https://gezimanya.com/mus.

Günal, N. (2013). Türkiye'de Kar Yağışı, Karın Yerde Kalma Süresi ve Daimi Kar Sınırı. Acta Turcica Online Thematic Journal of Turkic Studies, 5 (1), 1-13.

Gürer, B. (2017). The Research About Reasons of Mountaineers' Attend to Ice Climbing and Its Effects On Their Self-Confidence. European Journal of Education Studies, 3(8), 501-515. Doi: 10.5281/zenodo.841788

Howstuffworks, (2018). Can you ice climb a waterfall? (Erişim: https://adventure.howstuffworks.com/outdooractivities/climbing/waterfall-climbing.htm

Hungenberg, E., Gould, J. \& Daly, S. (2013). An examination of social psychological factors predicting skiers' skill, participation frequency, and spending behaviors. Journal of Sport ve Tourism, 18(4), 313-336.

HÜRRIYET (2009). Türkiye'nin kayak ve kaplıca merkezleri 2009. (Erişim: 10.12.2018), http://www.hurriyet.com.tr/turkiyenin-kayak-ve-kaplicamerkezleri-2009-11010536.

Kopar, İ., \& Çakır, Ç. (2015), Tortum Çayı Havzası'nda (Erzurum-Artvin) Donmuş Şelale-Çağlayan Tırmanışları ve Bunun Kış Turizmi Bakımından Önemi, Doğu Coğrafya Dergisi, 20(33), 63-90.

MGM (Meteoroloji Genel Müdürlüğü) (2018). Muş İli’ne ait iklim verileri. (Erişim: 02.12.2018), https://www.mgm.gov.tr/veridegerlendirme/il-ve-ilceleristatistik.aspx? $\mathrm{m}=\mathrm{MUS}$.

Milliyet (2017a). Güzeltepe Kayak Merkezi Sezona Hazır. (Erişim: http://www.milliyet.com.tr/guzeltepe-kayak-merkezisezona-hazir-mus-yerelhaber-2479389/.

Milliyet (2017b). Donan gölde buzlart 'motorlu testere'yle kesip balı avlyyorlar. (Erişim: 18.12.2018), http://www.milliyet.com.tr/ekonomi/donan-golde-buzlari-motorlu-testere-yle-kesip-balik-avliyorlar2576375/ekonomi/SonDakikaGaleri/20.12.2017/2576375/ default.htm.

Milliyet (2018). Muş'ta 'Lale' Festivali. (Erişim: 10.12.2018), http://www.milliyet.com.tr/mus-ta-lale-festivali-musyerelhaber-2763721/.

Muş İl Kültür Turizm Müdürlüğü (2018). Gezilecek Yerler. (Erişim: 10.12.2018), http://www.muskulturturizm.gov.tr/TR-56130/gezilecekyerler.html.

Muş Vakfi (2014). Muş'ta Turizm-Kış Turizmi. (Erişim: 06.12.2018), http://www.musvak.org.tr/musta-turizm/.

Muş Valiliği (2018a). Muş İlinin Tarihçesi. (Erişim: 02.12.2018), http://www.mus.gov.tr/ilimizin-tarihcesi. 
Muş Valiliği (2018b). Ulaşım. (Erişim: 06.12.2018), http://www.mus.gov.tr/ulasim-mus.

Muş Valiliği (2018c). Klş Turizmi. (Erişim: 06.12.2018), http://www.mus.gov.tr/kultur-ve-turizm.

Muş Web (2015). Kayak Merkezi Açıldı. (Erişim: 18.12.2018), http://www.mus.gen.tr/haber-29841-mus-kayak-merkeziacildi-haberi.html.

NTV (2018a). Turist sayısı 10 ayda 41 milyonu aştı. (Erişim: 30.11.2018), https://www.ntv.com.tr/seyahat/turist-sayisi10-ayda-41-milyonu-asti,1KKBbXcKWUWU-v0VPdeatg.

NTV (2018b). Seyahat Severlerin Yeni Gözdesi: Van Gölü Ekspresi. (Erişim: 06.12.2018), https://www.ntv.com.tr/galeri/seyahat/seyahatseverlerinyeni-gozdesi-vangoluekspresi,eoMSE9tuSEO19FBV5cJZPw.

UNWTO (2017). Tourism Highlights. (Erişim: 01.12.2018), https://www.eunwto.org/doi/pdf/10.18111/978928441902 9.

UNWTO (2018). 2017 International Tourism Results. (Erişim: 01.12.2018), http://media.unwto.org/press-release/201801-15/2017-international-tourism-results-highest-sevenyears.

T.C. Tarım ve Orman Bakanlığı XIV. Bölge Müdürlüğü (2018a). Akdoğan Gölleri Hakkında Bilgi. (Erişim: 18.12.2018) http://bolge14.ormansu.gov.tr/14bolge/SulakAlanlar/AK DOGAN.aspx?sflang=tr.

T.C. Tarım ve Orman Bakanlığı XIV. Bölge Müdürlüğü (2018b). Kazan (Haçlı) Gölü Hakkında Bilgi. (Erişim: 18.12.2018), http://bolge14.ormansu.gov.tr/14bolge/SulakAlanlar/HAC LI.aspx?sflang=tr.

TRT HABER (2018). Kurtik Dağı Nisan'da da Kayakçıları Ağırliyor. (Erişim: 01.05.2019) https://www.trthaber.com/haber/kultur-sanat/kurtik-daginisanda-da-kayakcilari-agirliyor-362640.html.

Tsiotsou, R. (2006). Using visit frequency to segment ski resorts customers. Journal of Vacation Marketing, 12(1), 15-26.

Tuppen, J. (2000). The restructuring of winter sports resorts in the french alps: problems, processes and policies. International Journal of Tourism Research, 2, 327-344.

TÜİK (2018a). Türkiye İstatistik Kurumu Dönemsel Gayrisafi Yurt İçi Hasıla Bülteni. (Erişim: 03.12.2018), http://www.tuik.gov.tr/HbGetirHTML.do?id=27825.

TÜİK (2018b). Türkiye İstatistik Kurumu Turizm İstatistikleri Bülteni. (Erişim: 03.12.2018), http://www.tuik.gov.tr/PreHaberBultenleri.do?id=27612

TÜİK (2018c). Türkiye İstatistik Kurumu Adrese Dayalı Nüfus Kayıt Sistemi Verileri. (Erişim: 03.12.2018), www.tuik.gov.tr/PreIstatistikTablo.do?istab_id=1590.

TÜİK (2018d). 2015 Yılı Illlere Göre Yaşam Indeksi. (Erişim: 06.12.2018), http://www.tuik.gov.tr/PreTabloArama.do.

Türkiye Kültür Portalı (2018). Haçlı (Bulanık) Gölü - Muş. (Erişim: 18.12.2018), https://www.kulturportali.gov.tr/turkiye/mus/gezilecekyer /hacli-bulanik-golu.

Silik, C.E. \& Ünlüönen, K. (2017). Kayak Merkezleri Kapsamında Yapılan Araştırmalara Yönelik Kavramsal Bir İnceleme. Journal of Recreation and Tourism Research, 4(4), 24-34.

Şengün, M. T. \& Kıranşan, K. (2016). BulanıkMalazgirt(Muş) Havzası'nın İklim Özellikleri. Bingöl Üniversitesi Sosyal Bilimler Enstitüsü Dergisi, 6(12): 2150.

Yeni Şafak (2017). Muş Havalimanı'na terminal. (Erişim: 07.12.2018), https://www.yenisafak.com/ekonomi/mushavalimanina-terminal-2773047. 